\section{Synchronizing Ripening in Individual 'Bartlett' Pears with Ethylene}

\author{
Laura Puig', Diane M. Varga', \\ Paul M. Chen ${ }^{1,2}$, and \\ Eugene A. M i e $1 \mathrm{ke}^{\mathrm{i}}$
}

Additional index words. Pyrus

communis, flesh firmness, extractable juice, dessert quality

Summary. 'Bartlett' pears (Pyrus communis $\mathrm{L}$. ) were harvested at commercial maturity (average flesh firmness of $18 \mathrm{lb}$ ), stored at $30 \mathrm{~F}$ for 0,2 , or 4 weeks, and then placed into a ripening room at $68 \mathrm{~F}$ with or without ethylene to evaluate ripening activities. Pears that were stored in air at $30 \mathrm{~F}$ for $<4$ weeks did not ripen after 7 days at $68 \mathrm{~F}$ in an ethylene-free (no-ethylene) room. These pears ripened normally and uniformly after 7 days at $68 \mathrm{~F}$ in a room enriched with 100 ppm ethylene (yes-ethylene).

'Bartlett' pears that were stored in air at $30 \mathrm{~F}$ for 4 weeks ripened normally after 5 days at $68 \mathrm{~F}$ in the yes-ethylene room or 6 days at $68 \mathrm{~F}$ in the noethylene room. The amount of cans produced per ton of fresh processed pears can be maximized most economically by exposing freshly harvested 'Bartlett' pears to $100 \mathrm{ppm}$ ethylene at $68 \mathrm{~F}$ for 7 days before canning.

A bout $70 \%(172,665$ tons processed out of a total production of 250,032 tons in 1994) of 'Bartlett' pears is used commercially for canning in the $\mathrm{Pa}$ cific Northwest (Newsletter of Washington-Oregon Canning Pear Asso-

${ }^{1}$ Mid-Columbia Agricultural Research and Extension Center, Oregon State University, 3005 Experiment Station Drive, Hood River, OR 97031-9512.

${ }^{2}$ To whom reprint requests should be addressed.

This research was support by funding from the Winter Pear Control Committee. Oregon State Agricultural Experimental Station technical paper no. 10,759. The cost of publishing this paper was defrayed in part by the payment of page charges. Under postal regulations, this paper therefore must be hereby marked advertisement solely to indicate this fact. ciation, 1994). The increase in overall pear production and limited fruit storage space in this region have forced the canning industry to process 'Bartlett' pears immediately after harvest. To maximize the number of cans obtained per lot of fresh pears (commercially termed case-yield), fruit within a lot must ripen at a uniform rate during storage at $68 \mathrm{~F}$ before processing (practically called a ripening cycle). If fruit do not ripen uniformly during a ripening cycle, a low case-yield is expected. The term uniform ripening implies that each fruit softens to a similar flesh firmness, has a similar amount of extractable juice, and develops similar flavor during a ripening cycle. Recently, the canning industry has experienced low case-yield of 'Bartlett' pears that were processed immediately after harvest or after only a short period of cold storage, and this low case-yield has been attributed to nonuniform ripening (personal communication; Truit Bros, Salem, Ore.).

It generally is recognized that ethylene induces the ripening activities of many fruit crops. One of the most striking characteristics of climacteric fruit is their capability to exhibit autocatalytic ethylene production (i.e., ethylene stimulates its own synthesis) (Pech et al., 1994). In most winter pear varieties, a period of chilling at storage temperatures between 30 and $32 \mathrm{~F}$ is required for inducing autocatalytic ethylene production (Pech et al., 1994). Low storage temperatures allow 1aminocyclopropane-1-carboxylic acid (ACC, the immediate ethylene precursor) to accumulate and, as a consequence, fruit start to produce ethylene and ripen normally upon exposure to room temperature. In other types of fruit such as apple and kiwi fruit, low temperatures hasten the induction of ethylene-synthesizing competency and homogeneous ripening (Pech et al., 1994). Although the effect of low storage temperatures on 'Bartlett' pear ripening has not been studied, Porritt (1964) reported that 'Bartlett' fruit harvested at late maturity with flesh firmness of $16.7 \mathrm{lb}$ required 10 days at $70 \mathrm{~F}$ or 13 days at $60 \mathrm{~F}$ to soften to $3 \mathrm{lb}$ if they had not been exposed to prior low storage temperatures. Flesh firmness of 'Bartlett' pears at optimum commercial maturity is between 19 and $17 \mathrm{lb}$ (Porritt, 1964). We frequently have observed that 'Bartlett' fruit harvested at optimum maturity 
do not ripen normally or they exhibit nonhomogeneous ripening at $68 \mathrm{~F}$ if fruit have not been exposed to the low storage temperature at $30 \mathrm{~F}$ or after $<15$ days of cold storage (personal observation). The time that elapses before a fruit starts to produce its own ethylene can be shortened by exposing the fruit to external ethylene. Earlier study showed that immature 'Bartlett' pears could be induced to ripen by exposing them to external ethylene (Hansen, 1967). By providing a constant flow of $200 \mathrm{ppm}$ ethylene in a ripening room, 'Bartlett' fruit picked 6 and 3 weeks before commercial harvest reached the respiratory climacteric peaks on day 11 and 7 , respectively, of the ripening period. In this study, we investigated the feasibility of commercially applying external ethylene to induce normal ripening and synchronize ripening of 'Bartlett' pears immediately after commercial harvest or after a short period of cold storage at $30 \mathrm{~F}$. The main goal is to create a practical ripening timetable, which will enable the cannery to maximize the case-yield of canned 'Bartlett' fruit early in the canning season.

'Bartlett' pears were harvested at commercial maturity (flesh firmness = $18 \pm 0.5 \mathrm{lb})(11 \mathrm{~b}=4.448 \mathrm{~N})$ from an orchard block at the Mid-Columbia Agricultural Research and Extension Center, Hood River, Ore., in 1994. Harvested fruit were transferred into 18 wooden boxes (44 lb/box) with polyethylene liners. Immediately after harvest, three boxes of fruit were placed into a ripening room enriched with ethylene at $100 \mathrm{ppm}( \pm 20 \mathrm{ppm})$ (designated as the yes-ethylene room) and another three boxes were placed in a ripening room with no ethylene $(<0.01$ ppm $\mathrm{C}_{2} \mathrm{H}_{4}$ ) (designated as the noethylene room). The temperature and the relative humidity in both rooms were maintained at $68 \pm 1 \mathrm{~F}$ and $75 \%$ $\pm 5 \%$ respectively. The remaining 12 boxes of harvested fruit were placed into $30 \mathrm{~F}$ storage for 2 or 4 weeks. After $1,3,5$, or 7 days of exposure to $68 \mathrm{~F}$ in the yes-ethylene or the no-ethylene room, 20 fruit from each box were removed to determine flesh firmness (FF) and extractable juice (EJ) according to Chen and Borgic (1985) and Chen and Mellenthin (1981). After 2 or 4 weeks of storage at $30 \mathrm{~F}$, three boxes of fruit samples were transferred into the yes-ethylene room and another three boxes were transferred into

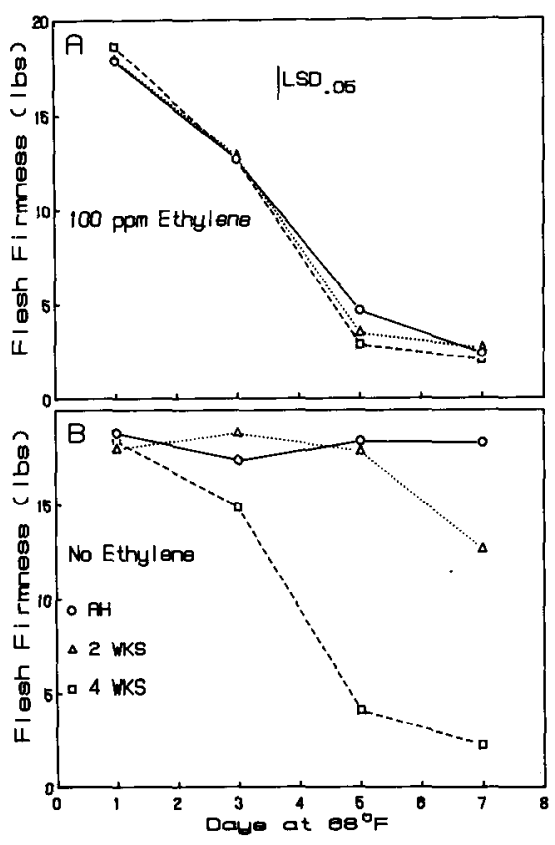

Fig. 1. Changes in flesh firnness $(F F)$ (softening pattern) of 'Bartlett' pears stored at $68 \mathrm{~F}$ in a yes-ethylene $(100 \pm 20 \mathrm{ppm})(\mathrm{A})$ or no-ethylene $(<0.01 \mathrm{ppm})(B)$ room for 7 days. Fruit were harvested on 15 Aug. 1994 with an average $F F$ of $18 \mathrm{lb}(1 \mathrm{lb}=4.448 \mathrm{~N})$, stored in wooden boxes (44 lb/box) ( $1 \mathrm{lb}=$ $0.454 \mathrm{~kg}$ ) with polyethylene liners in air at $30 F$ for $0(A H), 2$, and 4 weeks, and then stored in either the yes-ethylene room or the no-ethylene room at $68 \mathrm{~F}$.

the no-ethylene room at $68 \mathrm{~F}$. Fruit ripening indices were measured as described above.

After 6 days exposure to $68 \mathrm{~F}$ in the yes-ethylene or no-ethylene room, texture and flavor (acid/sugar balance and aroma) of the ripened fruit were assessed by three trained panelists and rated on a 9-point hedonic scale, with $9=$ buttery and juicy texture and excellent flavor and $1=$ mealy, coarse, and dry texture and off flavor (McBride, 1986). Each panelist was given the same fruit samples that were selected at random from each replicate. Three fruit per replicate were assessed at each ripening interval. The procedures for the sensory evaluation of horticultural crops (Heintz and Kader, 1983) were adopted by the panelists. Before sensory evaluations, the fruit were chilled at $30 \mathrm{~F}$ overnight and then warmed to $68 \mathrm{~F}$ for $2 \mathrm{~h}$. An average score of 5 or higher was arbitrarily defined as commercially acceptable.

After 5 or 7 days in the yes-ethylene or no-ethylene room, the frequency of individual fruit firmness was calculated to assess ripening uniformity. A total of 60 fruit (20 fruit per box) was

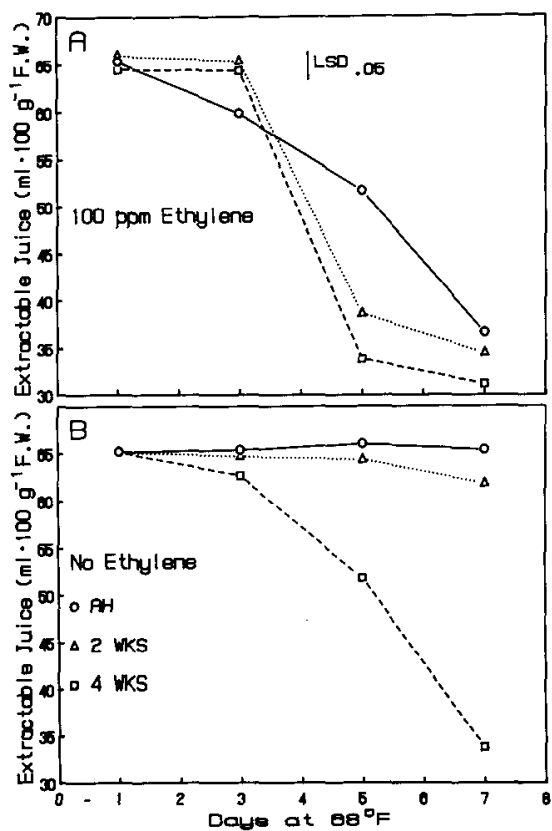

Fig. 2. Changes in extractable juice (EJ) of 'Bartlett' pears stored at $68 \mathrm{~F}$ in a yes-ethylene $(100 \pm 20 \mathrm{ppm})(\mathrm{A})$ or no-ethylene $(<0.01$ ppm) $(B)$ room for 7 days. Fruit were harvested on 15 Aug. 1994 with an average FF of $18 \mathrm{lb}(1 \mathrm{lb}=4.448 \mathrm{~N})$, stored in wooden boxes $(44 \mathrm{lb} / \mathrm{box})(1 \mathrm{lb}=0.454 \mathrm{~kg})$ with polyethylene liners in air at $30 \mathrm{~F}$ for $\mathrm{O}(\mathrm{AH})$, 2 , and 4 weeks, and then stored in either the yes-ethylene room or the no-ethylene room at $68 F$.

used to calculate the frequency distribution of fruit firmness.

Fruits stored in the yes-ethylene room at $68 \mathrm{~F}$ immediately after harvest without any prior $30 \mathrm{~F}$-storage softened to $4 \mathrm{lb}$ on day 5 and to $2 \mathrm{lb}$ on day 7 and had a concomitant reduction of EJ content (Figs. 1A and 2A). If these fruit were stored in the no-ethylene room at $68 \mathrm{~F}$, they softened very little and did not reduce in EJ content during 7 days of incubation (Figs. 1B and 2B). These results suggest that 'Bartlett' pears that are not exposed to $30 \mathrm{~F}$ require an external exposure to ethylene to induce normal ripening. After 2 weeks of storage in air at 30F, the fruit stored in the yes-ethylene room at $68 \mathrm{~F}$ softened to $3 \mathrm{lb}$ after 5 days and to $2.5 \mathrm{lb}$ after 7 days with concomitant reduction of their EJ content (Figs. 1A and 2A). On the other hand, fruit stored for 2 weeks at $30 \mathrm{~F}$ and then stored in the no-ethylene room at $68 \mathrm{~F}$ still had not softened sufficiently for commercial processing after 7 days (from 18 to $12 \mathrm{lb}$ ), and the EJ content in these fruit did not change (Figs. 1B and 2B). These results indicate that 2 weeks of chilling at $30 \mathrm{~F}$ did 


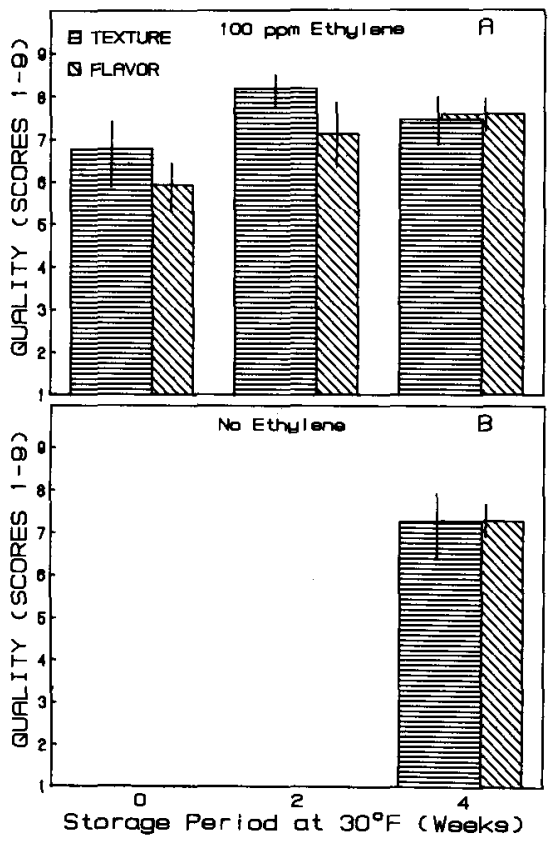

Fig. 3. Sensory evaluation of texture and flavor for ripened 'Bartlett' pears after 6 days of storage in a $68 \mathrm{~F}$ yes-ethylene (100 ppm \pm 20 ppm) (A) or no-ethylene $(<0.01 \mathrm{ppm})(B)$ room. The vertical line on each bar graph represent the standard error.

not induce ripening sufficiently after 7 days, and that an external ethylene treatment is required to induce a normal ripening process. After 4 weeks of storage in air at $30 \mathrm{~F}$, 'Bartlett' fruit softened similarly in yes- or no-ethylene rooms to $<4 \mathrm{lb}$ on day 5 and to 2 lb on day 7 (Fig. 1 A and B). The desirable firmness of ripened 'Bartlett' pears for commercial canning process ranges between 2 and $4 \mathrm{lb}$ with a 5/ 16-inch tip (personal communication, Truit Bros., Salem, Ore.). The amount of EJ in the fruit stored for 4 weeks at $30 \mathrm{~F}$ and then stored at $68 \mathrm{~F}$ with or without ethylene, however, changed differently during 7 days of $68 \mathrm{~F}$ storage. EJ in the fruit stored in yes-ethylene room decreased more dramatically (from $65 \mathrm{ml} / 100 \mathrm{~g}$ fresh weight on day 1 to $31 \mathrm{ml} / 100 \mathrm{~g}$ fresh weight on day 5 of ripening) than $\mathrm{EJ}$ in the fruit stored in no-ethylene room (from 65 $\mathrm{ml} / 100 \mathrm{~g}$ fresh weight on day 1 to 51 $\mathrm{ml} / 100 \mathrm{~g}$ fresh weight on day 5 of ripening) (Fig. $2 \mathrm{~A}$ and $\mathrm{B}$ ). The changing pattern of $\mathrm{EJ}$ in the ripening pear fruit is an objective method for evaluating texture quality (Chen and Borgic, 1985). When pears are ripening normally, water-soluble polyuronides in the pulp tissues increase dramatically, resulting in an apparent increase in hydroscopic binding capacity of the

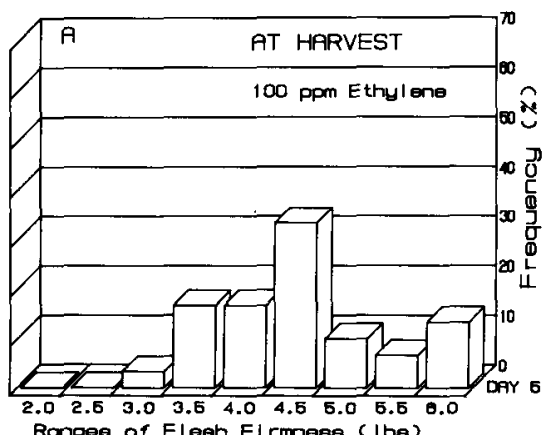

Range日 of Fleeh Fi rmmose (Ibe)

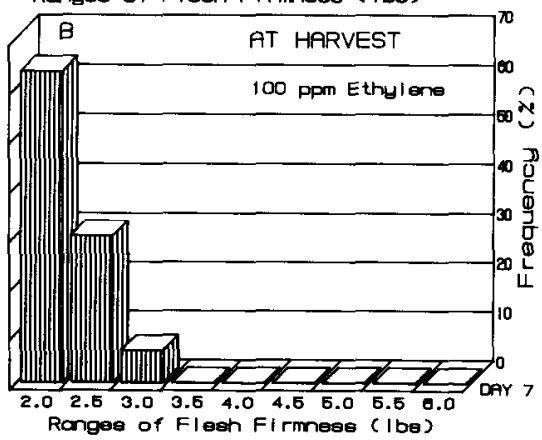

Fig. 4. Frequency of flesh firmness $(\mathrm{lb})$ of 'Bartlett' fruit after 5 days $(A)$ or 7 days $(B)$ in a $68 \mathrm{~F}$ yes-ethylene (100 ppm ethylene) room without prior storage at $30 F$.

ripening pulp tissues (predominantly the cell wall components). The phenomenon is consistent with the reduction of EJ in the ripening pulp tissues, which can be measured easily by a 1-

Fig. 5. Frequency of flesh firmness ( $l b)$ of 'Bartlett' fruit after 5 days $(A)$ or 7 days $(B)$ in a $68 \mathrm{~F}$ yes-ethylene (100 ppm ethylene) room with 2 weeks of prior storage at $30 \mathrm{~F}$.
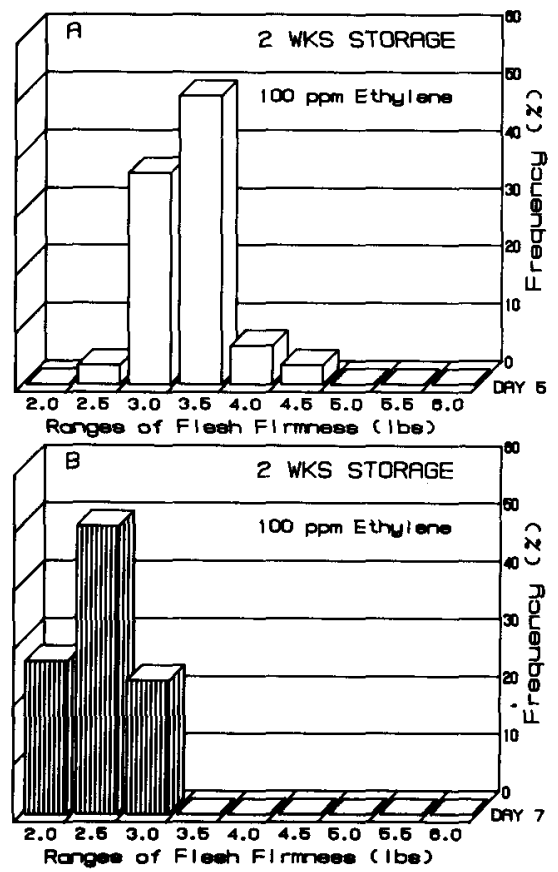

Fig. 6. Frequency of flesh firmness $(\mathrm{lb})$ of 'Bartlett' fruit after 5 days (A) or 7 days $(B)$ in a $68 \mathrm{~F}$ yes-ethylene (100ppm ethylene) room with 4 weeks of prior storage at $30 F$.
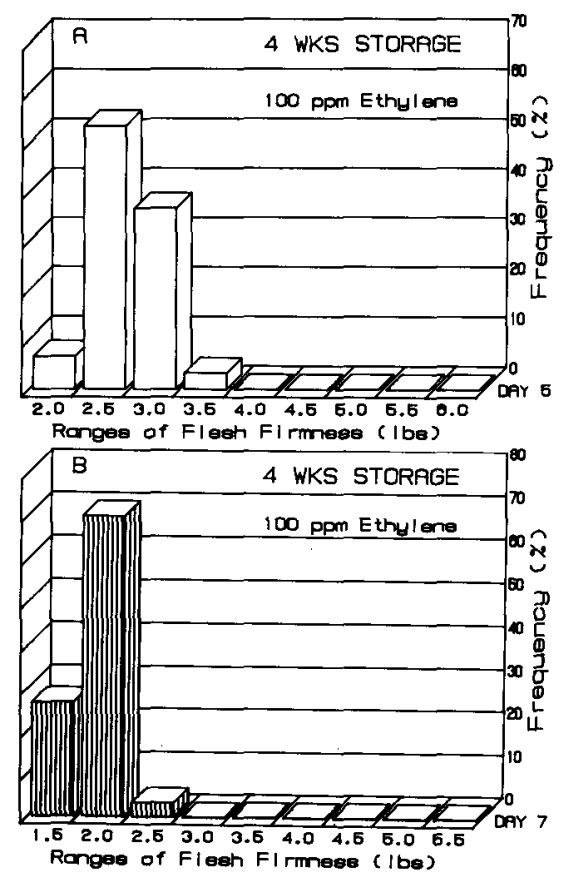

HortTechnology • Jan./Mar. 1996 6(1)

speed centrifugal juicer (Chen and Borgic, 1985). The ripened pear fruit with buttery and juicy texture usually have a higher reduction of EJ than pears with coarse and dry texfruit from both treatmen, duced to the same level of about $31 \mathrm{ml}$ (Fig. $2 \mathrm{~A}$ and B). If the fruit could soften normally with an apparent reduction of EJ to $<40 \mathrm{ml} / 100 \mathrm{~g}$ fresh weight upon ripening, they developed good texture regardless of ethylene fruit with (Fig. 3 A and B). Ripened developed good flavor (Fig. $3 \mathrm{~A}$ and B). These results indicate that 'Bartlett' ripen with good dessert quality after 5 after 7 days in a $68 \mathrm{~F}$ no-ethylene room.

The flesh firmness of pears that were not exposed to $30 \mathrm{~F}$ ranged from 3 to $6 \mathrm{lb}$ after 5 days of storage at $68 \mathrm{~F}$ in the yes-ethylene room, indicating that the fruit did not ripen uniformly (Fig. 4A). However, these ethylenetreated fruit softened uniformly to between 2 and $3 \mathrm{lb}$ (the proper firmness range for canning process) after 7 days of storage at $68 \mathrm{~F}$ (Fig. 4B). There, storage for 7 days in a $68 \mathrm{~F}$ yesethylene ripening room is preferred for the cannery to maximize the casefruit stored in air at 30F for 4 weeks can 

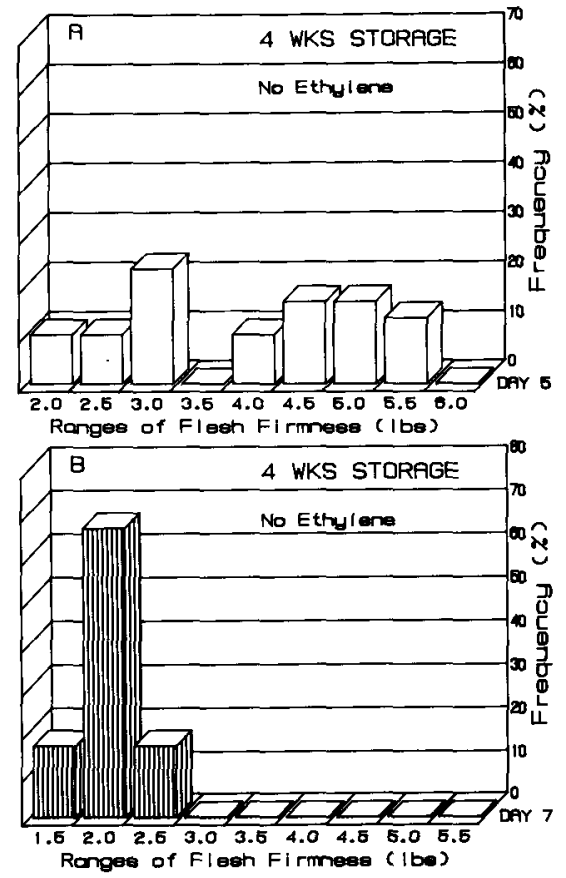

Fig. 7. Frequency of flesh firmness (lb) of 'Bartlett' fruit after 5 days $(A)$ or 7 days $(B)$ in a $68 \mathrm{~F}$ no-ethylene ( $<0.01 \mathrm{ppm}$ ethylene) room with 4 weeks of prior storage at $30 F$.

yield of the fruit lots processed immediately after harvest. The flesh firmness of pears stored for 2 weeks at $30 \mathrm{~F}$ plus 5 days at $68 \mathrm{~F}$ in a yes-ethylene room was between 2.5 and $4.5 \mathrm{lb}$ (Fig. 5A). Since $4 \mathrm{lb}$ firmness is the standard for canning, about $10 \%$ of these fruit was still too firm (4 to $4.9 \mathrm{lb}$ ) to meet the canning standard. After 7 days storage in the yes-ethylene room at $68 \mathrm{~F}$, pear flesh firmness was 2 to $3 \mathrm{lb}$ (Fig. 5B). These results indicate that storage at $68 \mathrm{~F}$ for 7 days in the yes-ethylene room was also necessary to maximize the case-yield of the fruit to be processed after 2 weeks of cold storage. After 4 weeks of 30F storage, fruit stored in the $68 \mathrm{~F}$ yes-ethylene room for 5 days softened uniformly to between 2 and $3.5 \mathrm{lb}$ (Fig. 6A). After 7 days in the $68 \mathrm{~F}$ yes-ethylene room, about $28 \%$ of these fruit had a FF of 1.5 to $1.9 \mathrm{lb}$ (Fig. 6B) and were probably too soft to be processed. Therefore, a 5-day storage in the yes-ethylene room at $68 \mathrm{~F}$ would be preferred for canning 'Bartlett' fruit that had been stored for 4 weeks at $30 \mathrm{~F}$. Fruit stored for 4 weeks at $30 \mathrm{~F}$ and then stored at $68 \mathrm{~F}$ for 5 days in a no-ethylene room softened to 2 to $5.5 \mathrm{lb}$ (Fig. 7A). These fruit were not suitable for canning because they softened rather unevenly. After 7 days in the $68 \mathrm{~F}$ no-ethylene room, fruit softened uniformly to 1.5 to $2.5 \mathrm{lb}$ (Fig. 7B). Again, 18\% of ripened fruit softened to $<2 \mathrm{lb}$ and would be overripe for canning. Perhaps a 6-day storage in the $68 \mathrm{~F}$ noethylene room might be preferred for fruit that have been stored previously for 4 weeks at 30F.

Since 'Bartlett' fruit in this study could ripen normally in the no-ethylene room when the fruit had been stored in air at $30 \mathrm{~F}$ for 4 weeks, we did not pursue further experiments with fruit stored for 5 weeks or longer at $30 \mathrm{~F}$, assuming that ripening would be adequate for canning.

In conclusion, we propose the following recommendations for ripening 'Bartlett' pears to maximize the case-yield for commercial canning process.

1) Fruit without previous exposure to storage temperature at $30 \mathrm{~F}$ or that have been stored at $30 \mathrm{~F}$ for < 3 weeks should be ripened in a 68F-room enriched with $100 \mathrm{ppm}$ ethylene for 7 days.

2) Fruit that have been stored at $30 \mathrm{~F}$ for 3 to 4 weeks should be ripened in a 68 F-room enriched with $100 \mathrm{ppm}$ ethylene for 5 days or in a $68 \mathrm{~F}$ no-ethylene room for 6 days.

3) Fruit that have been stored at $30 \mathrm{~F}$ for longer than 4 weeks should be handled with the normal commercial canning process.

\section{Literature Cited}

Chen, P.M. and W.M. Mellenthin. 1981. Effects of harvest date on ripening capacity and postharvest life of 'd'Anjou' pears. J. Amer. Soc. Hart. Sci. 106:38-42.

Chen, P.M. and D.M. Borgic. 1985. Changes in water soluble polyuronides in the pulp tissue of ripening 'Bose' pears following cold storage in air or in $1 \%$ oxygen. J. Amer. Soc. Hort. Sci. 110:667-671.

Hansen, E 1967. Ethylene-stimulated metabolism of immature 'Bartlett' pears. Proc. Amer. Soc. Hort. Sci. 91:863-867.

Heintz, C.M. and A.A. Kader. 1983. Procedures for the sensory evaluation of horticultural crops. HortScience 18:18-22.

McBride, R.L. 1986. Hedonic rating of food: Single or side-by-side sample presentation? J. of Food Tech. 21:355-363.

Pech, ], C. Balagur, A. Latche, and M. Bouzayen. 1994. Postharvest physiology of climacteric fruits: recent developments in the biosynthesis and action of ethylene. Sci. Des Aliment 14:3-15.

Porritt, S. W. 1964. The effect of temperature on postharvest physiology and storage life of pears. Can. J. Plant Sci. 44:568-579. 